\title{
ARATICUM ACCESSIONS: EFFECT OF GIBBERELLIC ACID CONCENTRATIONS AND SOAKING TIMES ON SEED DORMANCY OVERCOMING ${ }^{1}$
}

\author{
EDVAN COSTA DA SILVA ${ }^{2}$, FABÍOLA VILLA $^{3 *}$, DANIEL FERNANDES DA SILVA ${ }^{3}$, JEAN CARLO POSSENTI $^{4}$, \\ LUCIANA SABINI DA SILVA ${ }^{2}$, GIOVANA RITTER ${ }^{2}$
}

\begin{abstract}
The germination process of the Annona sylvatica A.St.-Hil becomes difficult because the seeds have physical and physiological numbness. Although, the objective was to evaluate the effect the gibberellic acid can have in overcoming this physiological process. So that, aimed to evaluate the effect of the gibberellic acid in the overcoming dormancy of araticum seeds. Two different projects were developed simultaneously (plants germination in the laboratory and emergence of seedlings in seed). At the laboratory, the experimental design used was completely casualized in factorial scheme $4 \times 4$. Evaluating the physiological aspect of the germination and vigor. The germination of the seeds presented superior performance when they were immersed in $1200 \mathrm{mg} . \mathrm{L}^{-1}$ of $\mathrm{GA}_{3}$, in $24 \mathrm{~h}$ of imbibition, reaching $67 \%$ of germination. In the emergence of seedlings in seed, the experimental design used was to randomize blocks in factorial scheme 4 x 5 (four accesses $\mathrm{x}$ five periods of immersion). After 110 days, evaluating physiological aspects of emergence and vigor. The emergence varied between 32 to $45 \%$ (accesses A1 and A3) in a period of 15 to $24 \mathrm{~h}$ (accesses A1 and A3 or A4). High concentration and longer period of soaking in gibberellic acid promote a bigger germination of the araticum seeds. There is a difference between the accesses of the species, necessary to evaluate before being collected, and in the present study the accesses A3 is promising for harvest.
\end{abstract}

Keywords: Physical scarification. $\mathrm{GA}_{3}$. Germination. Sexual propagation.

\section{ACESSOS DE ARATICUM: EFEITO DE CONCENTRAÇÕES DE ÁCIDO GIBERÉLICO E TEMPOS DE EMBEBIÇÃO NA SUPERAÇÃO DE DORMENCIA DE SEMENTES}

\begin{abstract}
RESUMO - O processo germinativo da Annona sylvatica A.St.-Hil. torna-se difícil porque as sementes apresentam dormência física e fisiológica. Porém, o ácido giberélico pode atuar na superação desse processo fisiológico. Assim, objetivou-se avaliar o efeito do ácido giberélico na superação de dormência em sementes de araticum. Foram desenvolvidos dois trabalhos distintos e simultaneamente (germinação de sementes em laboratório e emergência de plântulas em sementeira). Em laboratório, o delineamento experimental utilizado foi inteiramente casualizado em esquema fatorial 4 × 4 [quatro concentrações de ácido giberélico $(0,400,800 \mathrm{e}$ $1200 \mathrm{mg} . \mathrm{L}^{-1}$ x quatro períodos de imersão na solução $(0,8,16$ e $\left.24 \mathrm{~h})\right]$, avaliando-se os aspectos de germinação e vigor. A germinação de sementes apresentou desempenho superior quando foram embebidas em $1200 \mathrm{mg} . \mathrm{L}^{-1}$ de $\mathrm{GA}_{3}$ em 24 h de embebição, alcançando $67 \%$ de germinação. Na emergência de plântulas em sementeira, o delineamento experimental utilizado foi em blocos casualizados em esquema fatorial 4 x 5 [quatro acessos $\mathrm{x}$ cinco períodos de imersão $(0,18,20,22$ e 24 h). Após 110 dias, avaliou-se aspectos fisiológicos de emergência e vigor. A emergência variou entre 32 a 45\% (acessos A1 e A3) num período de 15 a 24 horas (acessos A1 e A3 ou A4). Alta concentração e maior período de embebição em ácido giberélico promove maior germinação de sementes de araticum. Existe diferença entre os acessos da espécie, necessário avaliação das mesmas antes da coleta, e no presente estudo o acesso A3 é promissor para coletas.
\end{abstract}

Palavras-chave: Escarificação química. $\mathrm{GA}_{3}$. Germinação. Propagação sexuada.

${ }^{3}$ Agricultural Sciences Center, Universidade Estadual do Oeste do Paraná, Marechal Cândido Rondon, PR, Brazil; fvilla2003@hotmail.com - ORCID: 0000-0002-3739-5160,daniel_eafi@yahoo.com.br - ORCID: 0000-0003-2105-5839.

${ }^{4}$ Graduate Program in Agronomy, Universidade Tecnológica Federal do Paraná, Pato Branco, PR, Brazil; jpossenti@utfpr.edu.br - ORCID: 0000-0001-9030-6262.
} 


\section{INTRODUCTION}

Araticum (Annona sylvatica A.St.-Hil.) is a Brazilian native species geographically distributed from Pernambuco to Rio Grande do Sul States (LORENZI, 2016). It belongs to the Annonaceae family, which has 120 genera and around 2,300 species. Of these, 33 genera and about 250 species (FIGUEIREDO et al., 2016), occur in Brazil. Commercial plantations are uncommon since it is usually obtained from extractivism or informal sales of hand-made processed fruits and products (OLIVEIRA et al., 2018).

Araticum seeds germinate unevenly over 70 to 217 days (BRAGA FILHO et al., 2014). Such a heterogeneity is because of their endogenous or physiological dormancy due to poorly developed embryo organs, and their exogenous or physical dormancy due to impermeable integument (CARVALHO; NAKAGAWA, 2012; MACHADO et al., 2016). The latter prevents water uptake keeping seed water contents low; therefore, cell metabolism is practically zero, which prevents seeds from germinating for a relatively long time (RIBEIRO et al., 2009). As grafts must be prepared from seeds to produce commercial seedlings, the dormancy should be overcome. This requires greater knowledge and understanding by researchers (SILVA et al., 2011).

During germination, gibberellins $\left(\mathrm{GA}_{3}\right)$ induce production and/ or reactivation of several hydrolytic enzymes involved in solubilization of endosperm reserves (BARDIVIESSO et al., 2020). These phytohormones comprise a group of growth regulators with a broad spectrum of action to overcome seed dormancy, inducing $\alpha$-amylase gene expression by increasing mRNA levels to be translated (TAIZ et al., 2017).

To overcome dormancy in fruit seeds, some substances can be used such as gibberellic acid $\left(\mathrm{GA}_{3}\right)$, boosting germination and initial seedling development. Another important factor is the wide range of soaking times in acidic solution of fruit species, so that dormancy could be overcome (FERREIRA et al., 2019; SILVEIRA et al., 2019). A few studies have been carried out on $\mathrm{GA}_{3}$ application in Annonaceae species, such as Annona crassiflora (FREITAS; MACEDO, 2018; RIBEIRO et al., 2009), A. squamosa L. (MARTÍNEZ et al., 2016), and Rollinia mucosa (Jacq.) Baill. (COUTINHO et al., 2018; CAMPOS et al., 2015). These studies aimed to verify $\mathrm{GA}_{3}$ influence on overcoming dormancy and seed germination process. The results demonstrated that exogenous $\mathrm{GA}_{3}$ application increase emergence percentage and speed, as well as seedling dry biomass. They also showed that $\mathrm{GA}_{3}$ efficiency is related to high concentrations and longer seed soaking times. However, no study has evaluated dormancy overcoming in A. sylvatica seeds.
Studies on seeds of non-commercial fruit species are important to help produce rootstocks for grafting and hence quality seedlings, which can be used in the recovery of degraded areas. Given the above, our study aimed to evaluate the effect of gibberellic acid in overcoming the dormancy of araticum seeds.

\section{MATERIAL AND METHODS}

Two different studies were carried out simultaneously at the State University of Western Paraná (Unioeste), Campus of Marechal Cândido Rondon, Paraná State, Brazil. The first was conducted in the Laboratory of Seed Technology of Unioeste from March to June 2019. The second comprised sowing and was performed in the seedling nursery of the Horticulture and Protected Cultivation Station at Unioeste (54 $22^{\prime} \mathrm{W}$ longitude, $24^{\circ} 46^{\prime} \mathrm{S}$ latitude, and 420-m altitude), from April to August 2019.

Ripe araticum fruits were collected from four native plants (mother plants named accessions A1, A2, A3, and A4) in the Experimental Farm of the Nucleus of Experimental Stations of the Unioeste in February 2019. The accession plants were spaced about 5 to 20 meters apart and were, on average, 12to 16-m high. Fruits were collected based on their yellow color (ripeness). After collection, fruits were taken to the Laboratory of Seed Technology for epicarp removal. Then, they were placed in $5-\mathrm{L}$ plastic buckets and left to rest for $48 \mathrm{~h}$. Afterwards, seeds were washed in running water on a sieve (mesh 06, wire $23 \mathrm{BWG}$, rim $65 \mathrm{~cm}$ ) until total mucilage removal. Finally, seeds were placed to dry in a dry shaded ventilated area at room temperature $\left(25 \pm 2^{\circ} \mathrm{C}\right)$. Before setting the germination test, seeds were previously disinfected by immersion in sodium hypochlorite solution $(0.025 \%$ active chlorine) for $10 \mathrm{~min}$. Later, they were rinsed in running water to wash the integument completely.

The first experiment followed a fully randomized design and $4 \times 4$ factorial arrangement [four gibberellic acid $\left(\mathrm{GA}_{3}\right)$ concentrations: 0,400 , 800 , and $1200 \mathrm{mg} \mathrm{L}^{-1} \mathrm{x}$ four solution soaking times $(0,8,16$, and $24 \mathrm{~h})]$, with eight 25 -seed replications. The first germination count (FGC) was carried out on the $15^{\text {th }}$ day after experiment setup, together with the germination test, and results expressed in percentage $(\%)$. The germination test $(\mathrm{G} \%)$ was conducted with eight 25 -seed replications, following a method adapted from Freitas and Macedo (2018). Seeds were distributed on germitest papers moistened with distilled water until reaching 2.5 times its dry weight and placed in Gerbox boxes. These were arranged in a BOD chamber set at constant temperature $\left(25 \pm 2{ }^{\circ} \mathrm{C}\right)$, relative humidity (80-85\%), and photoperiod (12 h) (BRASIL, 2009). Germination was analyzed using the botanical 
criterion, in which seeds with primary root protrusion are deemed germinated, and results expressed as a percentage (\%). Daily counts from the $1^{\text {st }}$ to the $115^{\text {th }}$ day of the experiment were used to determine the germination speed index (GSI) according to Maguire (1962). Mean germination time (MGT) was used to calculate the average time to reach the maximum germination, using the equation of Edmond and Drapala (1958). Evaluations were made weekly from the first day after sowing (the $15^{\text {th }}$ day of experiment setup) until the $115^{\text {th }}$ day (SILVEIRA et al., 2019).

The second experiment followed a randomized block design and $4 \times 5$ factorial arrangement [seeds of four accessions (A1, A2, A3, and A4) $x$ five soaking times $(0,18,20,22$, and $24 \mathrm{~h}$ ), with seeds being treated in a $500 \mathrm{mg} \mathrm{L}^{-1}$ gibberellic acid solution], with four 50-seed replications. Evaluations were performed from the $100^{\text {th }}$ to the $143^{\text {rd }}$ day after the experiment setup. Emerged seedlings (ES) were considered as those with cotyledons above the surface and expressed as a percentage (\%). Emergence speed index (ESI) was calculated concurrently with ES assessment, using daily ES values in the equation proposed by Maguire (1962). Mean emergence time (MET) was used to estimate the average time to reach the maximum seedling emergence (in days), using the equation of Edmond and Drapala (1958). The experiment was conducted in a screened environment (30\% shading). Seeds were sown in a seedbed filled with medium texture sand, washed, and previously disinfected with sodium hypochlorite solution. Plots were irrigated through a micro-sprinkler system and manually weeded when necessary.

Data from both experiments were subjected to analysis of variance homogeneity by Bartlett's and normality by Shapiro Wilk's tests $(p>0.05)$. After variance analysis, quantitative variables were submitted to regression analysis by the SISVAR statistical software (FERREIRA, 2014).

\section{RESULTS AND DISCUSSION}

In the first experiment, the analysis of variance showed an interaction between gibberellic acid $\left(\mathrm{GA}_{3}\right)$ concentrations and seed soaking times for the first germination count (FGC), germination $(\mathrm{G} \%)$, and germination speed index (GSI). Mean germination time (MGT) was significant only for $\mathrm{GA}_{3}$.

FGC varied as a function of $\mathrm{GA}_{3}$ concentrations and soaking times (Figure 1A). All soaking times except 0 showed linear behavior, with the best results at $1200 \mathrm{mg} \mathrm{L}^{-1}$. Seeds soaked for 24 and $16 \mathrm{~h}$ reached 47 and $17 \%$ germination, respectively. Yet, seeds soaked for $8 \mathrm{~h}$ showed a quadratic behavior, with a minimum point of $1 \%$ germination at $265 \mathrm{mg} \mathrm{L}^{-1} \mathrm{GA}_{3}$. None of the $\mathrm{GA}_{3}$ concentrations had significant effects on non-soaked seeds. Such a result can be justified by the presence of immature embryos that had not completed development in araticum seeds (MACHADO et al., 2016). For Ferreira et al. (2015) and Rego et al. (2018), increases in embryo growth potential, including control of the embryonic axis and developing tissues (stem and root), may be linked to gibberellins.

The final germination count was like FGC (Figure 1B) and had superior performance in seeds soaked at $1200 \mathrm{mg} \mathrm{L}^{-1} \mathrm{GA}_{3}$, reaching $67 \%$ within $24 \mathrm{~h}$. Again, none of the $\mathrm{GA}_{3}$ concentrations had significant effects on non-soaked seeds.

Our results indicate that the concentration of $1200 \mathrm{mg} \mathrm{L}^{-1} \mathrm{GA}_{3}$ and soaking time of $24 \mathrm{~h}$ were suitable to overcome dormancy and stimulate germination, thus proving that higher GA concentrations and longer seed soaking times are best suited for $A$. sylvatica gemination. These results open the possibility for further studies focused on increasing this range.

Several authors have evaluated dormancy overcome in Annonaceae family seeds using GA. Despite the consensus on GA use, concentrations and soaking times may vary since its ideal concentration changes among plant species, thus reinforcing the need for adjustments.

GSI increased linearly (Figure 1C) at $24 \mathrm{~h}$ soaking, reaching 0.97 by using $1200 \mathrm{mg} \mathrm{L}^{-1} \mathrm{GA}_{3}$, which was the best result among all studied treatments. The other treatments showed a quadratic behavior as $\mathrm{GA}_{3}$ concentration varied for each soaking time but the control, which had no significance. The higher the GSI, the greater the average daily germination, reaching a maximum when all seeds germinated on the first day (MOTA et al., 2015). The concentration of $1200 \mathrm{mg} \mathrm{L}^{-1} \mathrm{GA}_{3}$ is higher than that found by Barros et al. (2019), who also studied the $\mathrm{GA}_{3}$ effect on dormancy overcome in $A$. crassiflora seeds. These authors obtained a better response at $1000 \mathrm{mg} \mathrm{L}^{-1} \mathrm{GA}_{3}$. Conversely, Pimenta et al. (2019), who also worked with $A$. crassiflora seeds, observed that $\mathrm{GA}_{3}$ concentrations from 1000 to $3000 \mathrm{mg} \mathrm{L}^{-1}$ had no significant differences.

MGT increased as $\mathrm{GA}_{3}$ concentrations were raised. The maximum concentration showed a 13day delay in germination when compared to the control. From a physiological point of view, $\mathrm{GA}_{3}$ has not shown any effect on seed vigor (Figure 1D). MGT is a useful parameter to evaluate a species occupation speed in a location. Our finding (MGT > 10 days) shows that araticum can be classified as a reasonably slow species (PICO-MENDOZA et al., 2020). 

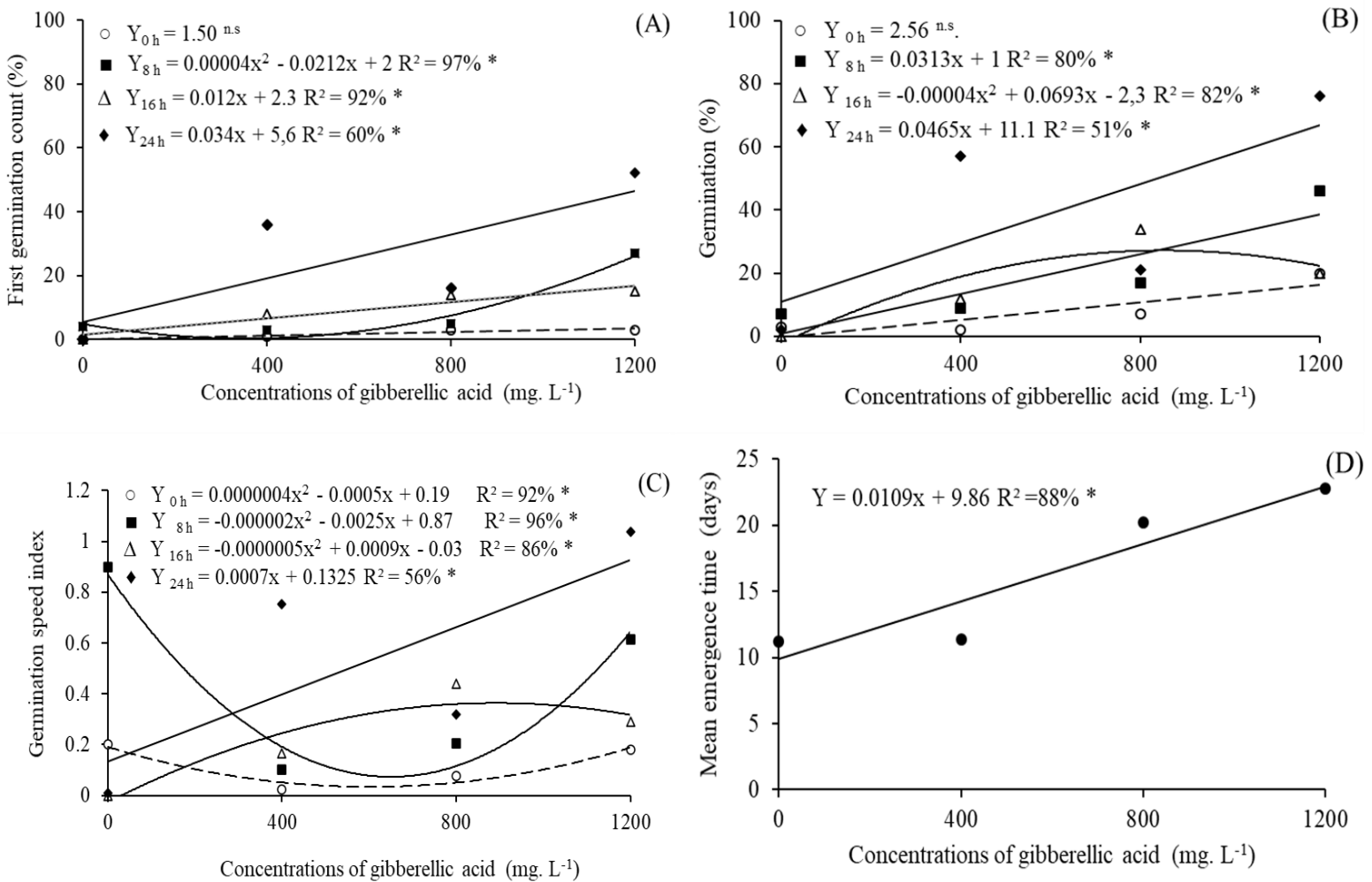

Figure 1. First germination count (A), germination (B), germination speed index (C) and mean germination time (D) of Annona syltvatica seeds as a function of concentrations and immersion periods in gibberellic acid solution.

In the second experiment, a significant interaction between soaking times and accessions was observed for all studied parameters, such as SE, ESI, and MET. The different accessions showed quadratic behavior for SE (Figure 2A); however, A2 showed no significant difference among soaking times. For other accessions, SE ranged from 32 to $45 \%$ (A1 and A3) within 15 to $24 \mathrm{~h}$ (A1 and A3 or A4).

As there are active gibberellins in seeds, minimal demands can be met and dormancy overcome naturally, as observed in the control treatment herein, which had a low ES. But, when we used $\mathrm{GA}_{3}$ within the soaking times of $18,20,22$, and $24 \mathrm{~h}$, ES percentages increased since $\mathrm{GA}_{3}$ stimulated the primary root growth disrupting the tissues restricting its growth, such as endosperm and seed tegument.

Campos et al. (2015) studied the $\mathrm{GA}_{3}$ effect on the emergence and growth of biribá (Rollinia mucosa) seedlings and observed that a dose of $1000 \mathrm{mg} \mathrm{L}^{-1}$ provided increases in ES percentages (from $5 \%$ to $87 \%$ ) and ESI (from 0.56 to 0.75 ). These outcomes corroborate ours for a soaking period of $24 \mathrm{~h}$ and phytoregulator concentration of $500 \mathrm{mg} \mathrm{L}^{-1}$.

ESI results (Figure 2B) were like ES ones (Figure 2A). A3 had the best result with a linear increase as soaking time was raised, reaching 0.18 at 24 h. Both A1 and A4 showed quadratic behavior, with a maximum point of 0.15 at $16 \mathrm{~h}$ and 0.19 at $38 \mathrm{~h}$, respectively. However, A2 showed no significant difference among the studied soaking times.

ESI is a key trait for fruit seedling production since the higher its value, the lower the seed exposure to adverse environmental conditions, such as fungal and insect attack, and the shorter the seedling permanence in nurseries, thus improving seedling production efficiency (DUTRA et al., 2012).

Rego et al. (2018) treated Annona muricata seeds with $\mathrm{GA}_{3}$ and observed that GSI also fitted a quadratic regression model. This might be associated with the capacity of gibberellins to induce enzyme synthesis, which promotes hydrolysis of seed reserve tissue and hence plant growth, speeding up and standardizing germination.

Although MET results of all accessions showed a quadratic behavior (Figure 2C), A1 and A3 showed no significant differences among soaking times. A Minimum MET of 125 days was recorded for A2 seeds at $9 \mathrm{~h}$ soaking, and A3 showed a minimum MET of 117 days at $15 \mathrm{~h}$. MET is the time at which $50 \%$ of the seeds emerged. This parameter was not deeply affected by the different soaking times in gibberellic acid studied. Therefore, this phytoregulator had a great influence on the final emergence of araticum seedlings. 

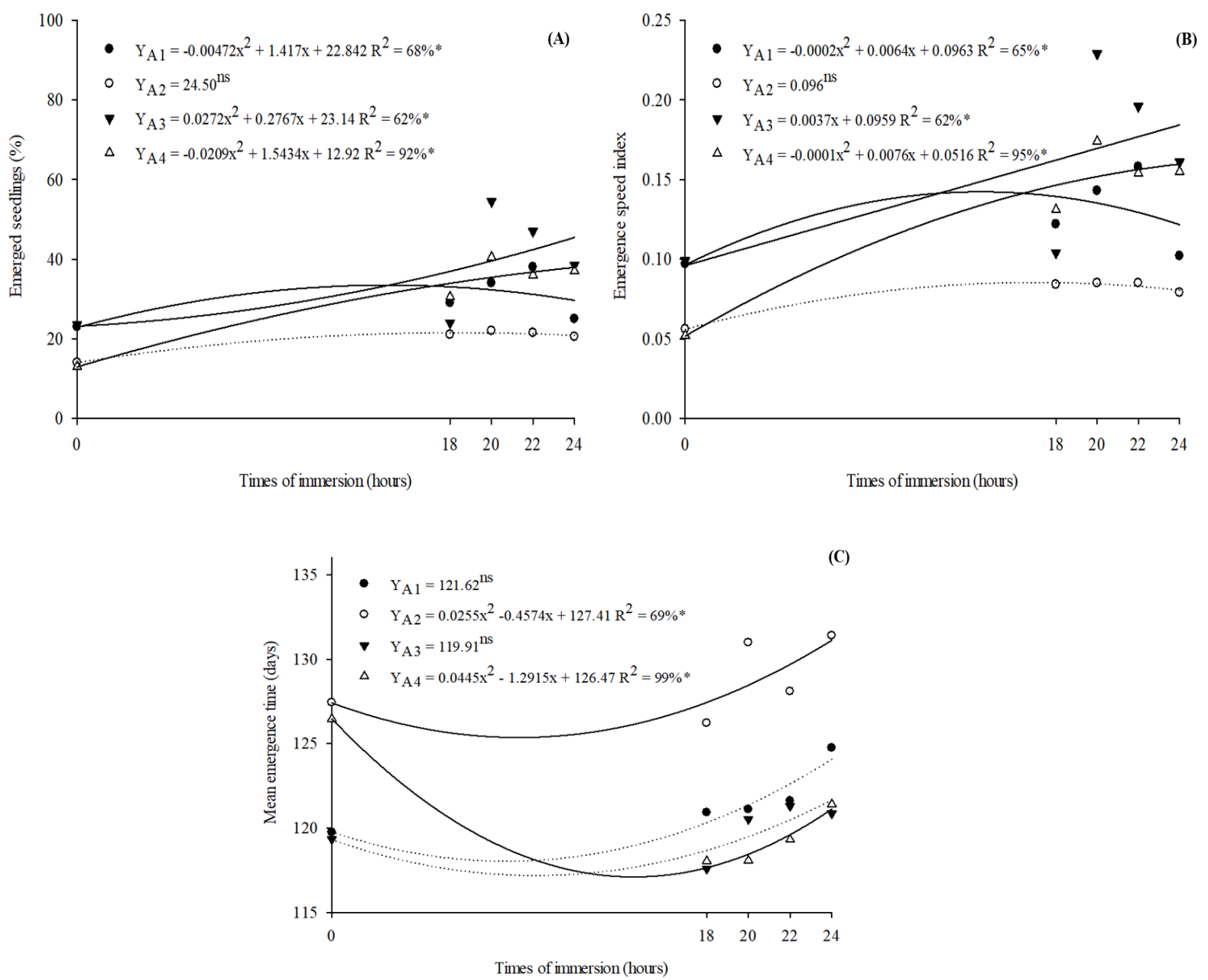

Figure 2. Seedling emergence (A), emergence velocity index (B) and mean time to emergence (C) of Annona syltvatica seeds as a function of accessions and immersion periods in gibberellic acid solution.

Araticum plants have high genetic variability since they come from seeds that have not yet undergone genetic improvements, thus generating highly different individuals. Plant breeders select parent plants (accessions) with genetically desirable properties from a population by seed collection. Such a process is essential to form seedbanks with greater genetic diversity (BELARMINO et al., 2017). Araújo et al. (2020) stated that genetic characterization of parent plants is as important as seed physiological quality for ensuring genetically diverse offspring.

There are few studies on breaking dormancy in araticum seeds in the literature. Accordingly, new studies are crucial to indicate better conditions for seed germination and performance of araticum seedlings.

\section{CONCLUSIONS}

Higher gibberellic acid concentrations and longer soaking times increase the germination of araticum seeds. Accessions of this species are diverse and should be evaluated before used as the parent material. Among the studied accessions, A3 showed to be promising for breeding programs.

\section{REFERENCES}

ARAÚJO, F. S. et al. Seed quality and genetic diversity of a cultivated population of Mimosa caesalpiniifolia Benth. Revista Caatinga, 33: 10001006, 2020. 
BARDIVIESSO, E. M. et al. Pre-germination treatments of paricá (Schizolobium amazonicum) seeds. Bioscience Journal, 36: 1090-1098, 2020.

BARROS, A. P. G. et al. Caracterização de frutos e sementes de araticum (Annona crassiflora Mart.) nativos do Cerrado Matogrossense. Agropecuária Científica no Semiárido, 14: 280-286, 2019.

BELARMINO, K. S. et al. Genetic diversity in a Poincianella pyramidalis (Tul.) L.P. Queiroz population assessed by RAPD molecular markers. Genetics and Molecular Research, 16: 1-10, 2017.

BRAGA FILHO, J. R. et al. Germinação de sementes e emergência de plântulas de araticum oriundos do Cerrado de Goiás. Bioscience Journal, 30: 74-81, 2014

BRASIL. Ministério da Agricultura, Pecuária e Abastecimento. Regras para análise de semente. Secretaria Nacional de Defesa Agropecuária. Departamento Nacional de Produção Vegetal. Coordenação de Laboratório Vegetal. Brasília, 2009. $365 \mathrm{p}$.

CAMPOS, L. F. C. et al. Escarificação e ácido giberélico na emergência e crescimento de plântulas de biribá. Ciência Rural, 45: 1748-1754, 2015.

CARVALHO, N. M.; NAKAGAWA, J. Sementes: ciência, tecnologia e produção. 4. ed. Jaboticabal, SP: FUNEP, 2012. 588 p.

COUTINHO, P. W. R. et al. Overcoming dormancy in seeds of biribá and seedling growth. Scientia Agraria Paranaensis, 17: 226-230, 2018.

DUTRA, T. R. et al. Emergência e crescimento inicial da canafístula em diferentes substratos e métodos de superação de dormência. Revista Caatinga, 25: 65-71, 2012.

EDMOND, J. B.; DRAPALA, W. J. The effects of temperature, sand and soil, and acetone on germination of okra seeds. Proceedings of American Society of Horticultural Science, 71: 428-434, 1958.

FERREIRA, D. F. Sisvar: a guide for its bootstrap procedures in multiple comparisons. Ciência $\mathbf{e}$ Agrotecnologia, 38: 109-114, 2014

FERREIRA, G. et al. Fisiologia da germinação e dormência de sementes de Anonaceae. In: ALMEIDA, J. R. G. S.; OLIVEIRA JÚNIOR, R. G.; OLIVEIRA, A. P. (Eds.). 1. ed., cap. 2. 2015. p. 3362.
FERREIRA, G. et al. Propagation of annonaceous plants. Revista Brasileira de Fruticultura, 4: 1-14, 2019.

FIGUEIREDO, F. R. S. D. N. et al. Avaliação da atividade anti-Leishmania e anti-Trypanosoma do extrato etanólico das folhas de Annona squamosa L. Acta Toxicológica Argentina, 24: 173-179, 2016.

FREITAS, J. A.; MACEDO, W. R. Germinação de sementes de araticum: doses de $\mathrm{GA}_{3}$ e períodos de embebição. Colloquium Agrariae, 14: 153-157, 2018 .

LORENZI, H. Árvores brasileiras: manual de identificação e cultivo de plantas arbóreas nativas do Brasil. 7. ed. São Paulo, SP: Instituto Plantarum de Estudos da Flora, 2016. 384 p.

MACHADO, C. G. et al. Biometria e caracterização morfológica de sementes de araticum, oriundas de matrizes de Palminopólis-GO. Global Science and Technology, 9: 41-47, 2016.

MAGUIRE, J. D. Speed of germination aid in selection and evaluation for seeding and vigour. Crop Science, 2: 176-177, 1962.

MARTÍNEZ, M. et al. Sugar apple (Annona squamosa L.) seed germination affected by the application of gibberellins. Agronomía Colombiana, 34: 17-24, 2016.

MOTA, A. R. et al. Efeito da substância húmica na germinação de sementes de Myracrodruon urundeuva Fr. All. Revista Verde de Agroecologia e Desenvolvimento Sustentável, 10: 26-30, 2015.

OLIVEIRA, E. C. T. et al. Licor de araticum (Annona crassiflora Mart.). 1. ed. 2018. 13 p. (Boletim Técnico IFTM, 4).

PICO-MENDOZA, J. et al. Germination capacity of Annona deceptrix (Westra) H. Rainer (Annonaceae) an endemic and endangered species in Manabí, Ecuador. Indian Journal of Agricultural Research, 54: 329-335, 2020

PIMENTA, A. C. et al. Giberelina na superação de dormência de sementes de araticunzeiro (Annona crassiflora Mart. - Annonaceae. Global Science and Technology, 12: 79-86, 2019.

REGO, C. H. Q. et al. Ácido giberélico auxilia na superação da dormência fisiológica e expressão de vigor das sementes de graviola. Revista de Agricultura Neotropical, 5: 83-86, 2018. 
RIBEIRO, M. N. O. et al. In vitro seed germination and seedling development of Annona crassiflora Mart. Scientia Agricola, 66: 410-413, 2009.

SILVA, P. E. M. et al. Quebra de dormência em sementes de Sesbania virgata (Cav.) Pers. Idesia, 29: 39-45, 2011.

SILVEIRA, M. B. et al. Superação de dormência de sementes de araticum do Cerrado. Biodiversidade, 18: 82-90, 2019.

TAIZ, L. et al. Fisiologia e desenvolvimento vegetal. 6. ed. Porto Alegre, RS: Artimed, 2017. 888

p. 